\title{
Electrothermomechanical Friction of Wet Elements of Automotive Disc-shoe Brakes
}

\author{
D.A. Volchenko ${ }^{1}$, M.V. Kindrachuk², N.A. Volchenko 3 , S.V. Nikipchuk4 ${ }^{4}$ M.M. Nasirova ${ }^{5}$, \\ N.B. Klochko ${ }^{1}$, A.O. Yurchuk ${ }^{2}$ \\ ${ }^{1}$ Ivano-Frankivsk National Technical University of Oil and Gas, 15, Karpat s'ka Str., \\ 76000 Ivano-Frankivsk, Ukraine \\ 2 National Aviation University, Liubomyra 1, Guzara Ave., 02000 Kyiv, Ukraine \\ ${ }^{3}$ Kuban State Technological University, 2, Moskov St., 350042 Krasnodar, Russia \\ ${ }^{4}$ National University "Lviv Polytechnic", 12, S. Bandera St., 79000 Lviv, Ukraine \\ ${ }^{5}$ Azerbaijan Aviation Academy, 30, Mardakan Prosp., Baku, Azerbaijan
}

(Received 16 August 2020; revised manuscript received 17 December 2020; published online 25 December 2020)

\begin{abstract}
In the article, attention is paid to the factors affecting the limiting wetting angle of both polished and matte side surfaces of solid and self-ventilated discs of vehicles' brake devices when they are moving on a wet roadbed. The following factors are considered: the material of the friction elements and its structure, the energy level of the surface layer, the topography of the friction surfaces and the geometric parameters of their microasperities, the presence of pores and grooves in them, capillary, centrifugal and inertial forces and moments, dynamic equilibrium between the energy level of the friction surface and a water film on it. In examining the microgeometry of the disc friction surface, its area, the ratio of the microasperities height to their pitch, the intensity of changes in their height and the degree of contamination were taken into account. It was found that the surface microgeometry affects the heat of desorption of the water film. The research of the above factors has shown that the driving force of the processes and effects in wet brake friction couples are potential gradients arising as a result of action of transverse and longitudinal electric double layers. The triboelectric water-effected phenomena were studied. The test results of self-ventilated disc-shoe brakes of MAN trucks (model TGA 26.420) with dry and wet friction couples tested with 20 -fold cyclic braking are presented (speed drop $30 \mathrm{~km} / \mathrm{h}$ per $1 \mathrm{~min}$ ). The registered temperature at the interface was $320-340^{\circ} \mathrm{C}$. As a result of the road tests carried out on a truck with wet brake friction couples, regularities of the braking time, braking torque and braking distance depending on the dynamic coefficient of friction were established. The analysis of the obtained data was carried out. The results of studies of the negative effect of water penetration into disc-shoe interface are given.
\end{abstract}

Keywords: Disc-shoe brake, Friction couple, Microasperity, Water, Steam, Longitudinal and transverse double electric layer.

DOI: 10.21272/jnep.12(6).06020

PACS numbers: 81.15. - z, 61.43.Gt, 52.40.Hf

\section{INTRODUCTION}

It is virtually impossible to imagine any ground vehicle without positive braking system. Most of them employ the combination of metallic and fibrous or carbon-based materials. It is known that steel brake discs are crystalline bodies consisting of a complex blocks system, fragments of grains and endings of separate groups of dislocations that form a thin relief or submicrorelief [1]. It may be original, as well as induced by high temperature and friction forces, especially when it contains dissimilar phases [2,3]. At the stage of operation, the disc has surface energy, which increases under the action of normal clamping forces due to the deformation component. The total surface energy of the disc friction belt varies from minimum to maximum during braking.

The polished and matt brake discs' surfaces have different topography. It is constant for matt surfaces of the discs, and on the other hand, for the friction belt of the disc - it changes due to frictional interaction. Along with the submicrorelief, a special microrelief zone is formed on disc's friction belt during the operation of the disc, the height of the microasperity of which is several orders higher than in submicrorelief.

At a certain point, a movable equilibrium is established between the energy levels of the friction belt surface of the disc and the water film on it, the thickness of which depends on the operating parameters of the brake friction couples. The surface energy substantially depends on the microgeometry and the stress-strain state of the surface layer, which are changing during friction. As a result, the state of the water film and the surface energy of the friction belt change.

\section{PROBLEM STATEMENT}

Friction couples of vehicle's disc-shoe brakes are not protected from dirt, moisture and atmospheric fallout when driving a vehicle over a water barrier or when operating in wet weather.

The operational integrity (contact strength, specific loads, energy loading, dynamic coefficient of friction, braking torque, wear properties) of brakes' friction couples depends on the thickness of the water layer over them. Consequently, the definition of the water layer thickness and its influence on the operational parameters of the brake mechanism is on the front burner.

Unprotected vehicle's disc-shoe brakes under speed conditions are forced to cool down by approaching airflows. When driving on a wet road, water and dirt fall into the friction belts of the discs, creating hydroplaning effect in the friction bunks, which significantly reduces the value of the dynamic coefficient of friction [1]. Wetting of the polished and matt surfaces of solid and selfventilated brake discs improves their forced cooling, 
however, significantly worsens the performance parameters of the brakes' friction couples and safety of vehicles. This is due to the fact that with the usual normal force on the brake pedal, a smaller force of pressing the pads against the disc will be created, the realized dynamic coefficient of friction and the friction force, as well as the developed braking torque will decrease, as a result of which the braking distance of the vehicle will increase. A different degree of wetting the discs' surfaces of the vehicle causes an imbalance of its braking forces on the front and back axles or in the brakes of the left and right sides. This can cause the vehicle to skid or drift to the side; unpredictable behavior of the vehicle on a wet road can lead to serious accidents.

During braking, locally contaminated and clean surfaces of discs' friction belts have different dynamic coefficient of friction.

Contamination of the friction belts of the vehicles brake discs leads to a decrease in the braking torque by at least two times.

There are studies concerning the influence of wetting the various types of surfaces made of heatconducting and non-heat-conducting materials [4,5], cold and heated friction couples [6-8] on their operational parameters $[9,10]$. Attempts to determine the amount of water contained in the microdepressions of friction surfaces [11-13], as well as the results of the above studies have shown that they do not sufficiently reflect the actual situation.

\subsection{Tasks to be Solved}

This publication addresses the following issues in relation to the problem being solved:

- hydrostatics of two-phase systems of friction couples irrigated with water;

- processes and effects arising from the frictional interaction of wet friction couples;

- the influence of wet friction couples on the operational parameters of the vehicles' disc-shoe brakes.

\subsection{Objectives}

The work objective is to investigate the irrigation of friction couples with water, to recognize the companion processes and effects occurring in the channels between the micro-protrusions of their working surfaces, and to evaluate the working efficiency of the wet friction units of vehicles' disc-shoe brakes.

\section{RESULTS OF THE RESEARCH}

\subsection{Hydrostatics of Two-phase Systems of Friction Couples Irrigated with Water}

It is known that phase boundaries are interpreted as geometric surfaces. Real interphase boundaries are thin transition layers of a complex structure. The molecules making up the transition layer (Fig. 1) interact with the molecules of both boundary phases, due to what the properties of the transition layer differ from the properties of substances in phase space volume. The formation of a new phase surface is associated with the work spent on transferring some of the molecules from the phase space volume to the surface transition layer.
The friction couple of the disc-shoe brake is made up of the working surfaces of the friction disc and the friction belt of the brake disc. During frictional interaction under pressing force $N$, the microasperities of the disc friction belt are penetrating into the working surface of the friction pad. The microasperities of the friction belt of the rotating disc furrow the surface layer of the lining during braking, thus creating channels of variable profile in it. The formed channels have gaps between the microasperities of the disc friction belt and during friction their cross-section increases.

While investigating, the size and location of microasperities on the friction surface are randomly selected, herewith the resulting relief must satisfy a certain distribution law and have surface energy. It has been established that a layer of water that has fallen into the areas of the friction belt of a solid disc is subjected to the action of a normal force from the working surface of the pad and has surface energy. Mathematically, we have:

$$
\gamma=\frac{N}{l}
$$

where $l$ is the interface thickness in a perpendicular direction to the force.

At a later stage, the equality is considered:

$$
\gamma d A=\gamma l d x
$$

where $\gamma d A$ is the surface energy increment.

$$
d \omega_{\mathrm{T}}=\gamma d A,
$$

where $d \omega_{\mathrm{T}}$ is the surface tension that is defined as the work required to increase the surface area of a water film per unit area (Fig. 2).

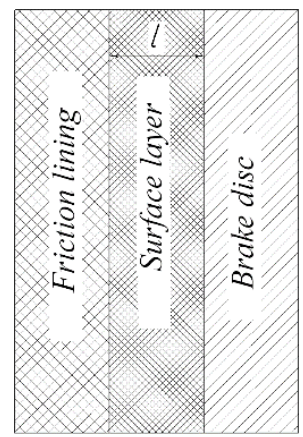

Fig. 1 - Surface layer of thickness $l$ be tween two phases

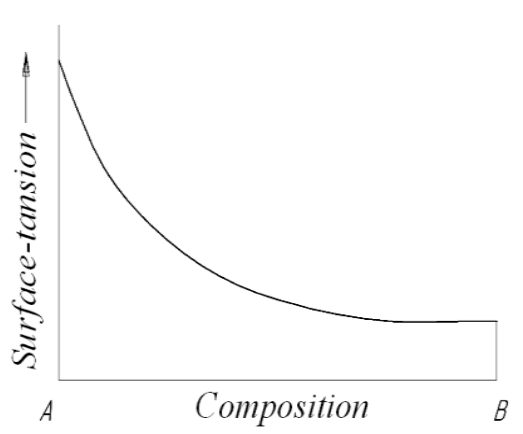

Fig. 2 - Change of the surface tension in a two-component system
The water surface tension $\gamma$ at the disc friction belt is defined as the irreversible work of creating a new surface by adding other atoms to the surface. This work contributes to the deformation of the friction belt surface and is the distortion measure of the surface areas under compression and thermal expansion. The values of surface tension and compression are equal for the water, but for a metal disc friction belt, they are different. The effect of surface tension is most clearly expressed in the spherical water droplets formation, which is associated with minimization of the surface area and its energy. The 
formation of a water film comes with an increase in free energy. For constant $p$ and $T$ :

$$
\Delta G=\int_{A_{1}}^{A_{2}} \gamma d A=\gamma\left(A_{2}-A_{1}\right)
$$

The values of the surface energy for water and steam vary in very wide ranges from $0.072 \mathrm{~J} / \mathrm{m}^{2}$ for metals: aluminum oxide (solid) $-0.91 \mathrm{~J} / \mathrm{m}^{2}$, titanium carbide (solid) - $1.19 \mathrm{~J} / \mathrm{m}^{2}$. In general, the surface energy for metals can exceed similar values for water and steam by $15-22 \%$.

\subsection{Processes and Effects Arising from the Fric- tional Interaction of Wet Friction Couples}

New effects appear with the surfaces curvature of the wet friction belt microasperities of the slow-rotating brake disc which interacts with the working surface of the polymer lining. These effects make it possible to determine the degree of water bubble expansion and the surface tension of the water meniscus in the capillary [14].

For an equilibrium configuration of the water layer located on the disc friction belt, it is natural to expect such a surface shape that corresponds to the minimum energy. If the energy of "friction zone - water" interface $\left(\gamma_{3}\right)$ is high, water on the friction zone will form a sphere (Fig. 3a). If the energy of the "friction belt-moisture" interface $\left(\gamma_{1}\right)$ is high, then the water will spread along the friction belt (Fig. 3c). A transitory case is shown in Fig. 3b.

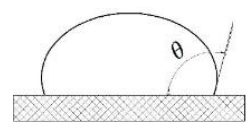

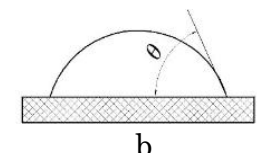

b

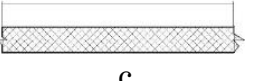

Fig. 3 - Types of wetting: non-wetted surface, $\theta>90^{\circ}$ (a); wetted surface, $\theta<90^{\circ}(\mathrm{b})$; spreading of water over the surface of a solid object, $\theta=90^{\circ}$ (c)

The angle between the surface of the friction belt and the tangent to the water surface drawn from the intersection point of the drop perimeter with specified surface is called contact. It can vary from $0^{\circ}$ to $180^{\circ}$. The value of this angle determines the conditions for the minimum energy according to the equation:

$$
\gamma_{3} \cos \theta=\gamma_{1}-\gamma_{2},
$$

where $\gamma_{1}, \gamma_{2}, \gamma_{3}$ are the interphase energies. At $\theta<90^{\circ}$, water rises in the capillary. Spreading of water corresponds to the condition when water completely covers the surface (Fig. 3c). In order to determine the surface wetting ability, the spreading coefficient is introduced:

$$
S_{4}=\gamma_{1}-\left(\gamma_{3}+\gamma_{2}\right) \text {. }
$$

When water spreads on the surface of the friction belt, the value of $S_{4}$ is positive. In particular, $\gamma_{3}<\gamma_{1}$.

Imagine a friction couple of a disc-shoe brake is a capacitor. Then the presence of differential capacities in the form of microchannels filled with water makes it possible to explain many of the effects arising near the charged boundary surface. At the boundary surface, there may be adsorbed chemical ions, in this case anions which have the same sign as the working surface of the metal friction element of the brake device. These anions are dehydrated and the inner Helmholtz plane passes through their centers. The Stern layer is formed mainly by electrostatically adsorbed cations, through the centers of which the outer Helmholtz plane passes. In this case, most of the surface is occupied by water molecules. On a highly charged surface, the concentration of adsorbed ions is very low.

The structural features of the electric double layer of a static friction metal element are shown in Fig. 4. A different picture is observed with the electrothermomechanical frictional interaction of the brake friction couples.

The presence of a dynamic layer of water between microasperities of the disc friction belt and the thermal layer of water between the microasperities of the friction pad at different thermal states brings significant changes into the scheme mentioned earlier. The repolarization of ions and electrons occurs, the position of the microscopic channels changes with each rotation of the brake disc by an angle of $\pi / 2$ and the electrical properties of ions and electrons change. The surface of the water layer becomes inhomogeneous, since its structure is disrupted by adsorbed particles of the facing material. It should be noted that other components also make changes to the above processes and effects.

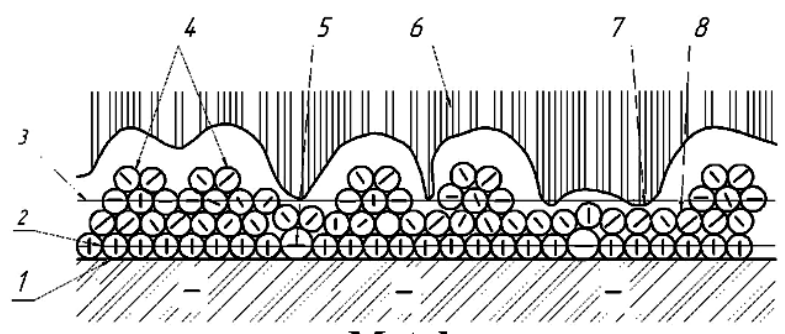

Metal

Fig. 4 - Detailed model in "metal-water" couple: 1-metal surface; 2, 3-Helmholtz and Gui surfaces; 4 - solvate cations; 5 - specific adsorbed anions; 6 -normal structure of water; 7,8 - layers of water

It has been established that two double electric layers are formed in the brake friction couples: the first is the surface of the microasperities' tops of the disc friction belt (negatively charged) - a layer of water between the microasperities (negatively charged); the second is the surface of the microasperities' tops of the friction pad (positively charged) - a layer of water between the microasperities (negatively charged) [15-21]. Fig. 5 shows the interaction pattern of electric fields between unlike (a) and like (b) charges.
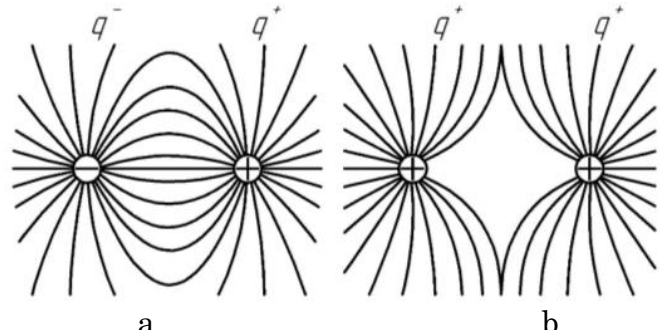

$\mathrm{b}$

Fig. 5 - Interaction pattern of electric fields between unlike (a) and like (b) charges 
As a characteristic size, we take the equivalent hydraulic diameter, thereby reducing all cases of channels of a complex profile to some equivalent circular channel with a diameter $d$ :

$$
d=4 A_{0} / P
$$

where $A_{0}$ is the channel cross-section; $P$ is the perimeter of the channel's cross-section wetted with water. With an increase in the radius $R$ of the microgroove and a decrease in the depth $h$, the degree of wettability and the spreading rate of the water upper layer across the furrows increase. In this case, double electrical layers are formed: the first one is "the working surface of the pad - the upper semi-layer of water", the second "the lower half-layer of water - the surface of the disc's friction belt". When $\varphi_{\mathrm{I}}-\varphi_{\mathrm{II}}>0$, the difference in potential arises between the half-layers. This contributes to the fact that the lower half-layer of water seems as if it sticks to the surface of the furrow. It was found that the microgeometry of the furrows on the disc friction belt affects the value of heat desorption of the lower half-layer, which makes the disc less controllable.

Let us analyze the regularities in changes in the contact angle of the water meniscus in the microchannel for one revolution of the disc. Imagine that the friction pad with its working surface covers a quarter of the disc's friction belt surface. In the microchannel, the water will rise to the specified level at a wetting angle $\theta_{1}$ (Fig. 6a). In the second quarter, the radius of the water meniscus curvature will increase (Fig. 6b), since the contact angle $\theta_{2}$ decreases. In the third quarter, the water meniscus becomes convex and is ready to leave the microchannel space as a drop (Fig. 6c) as the contact angle $\theta_{3}$ decreases. In the fourth quarter, the water meniscus in the microchannel had changed its shape (Fig. 6d), and the contact angle $\theta_{4}$ decreased significantly. Thus, the greater the contact angle gradient is, i.e. $\theta_{1}-\theta_{2}, \theta_{2}-\theta_{3}, \theta_{3}-\theta_{4}$, the faster water will spread over the surface of the friction belt forming films on it.

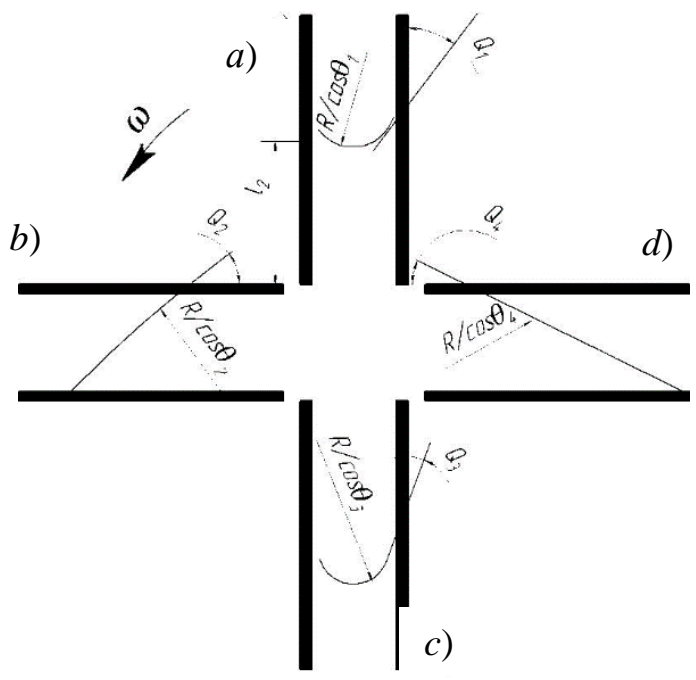

Fig. 6 - Forms of the water meniscus in cylindrical channels formed in friction couples during braking

The imposition of an external electric field (due to the presence of charges in water) arising from the frictional interaction of friction surfaces' microasperities, causes electroosmotic effect, i.e. movement of water along the channel. In fact, this is the only accessible and widely used method of pumping water through various nano- and micro-hydraulic systems. Electroosmotic pump ensures the speed of water movement and this speed depends on the strength $E$ of the applied field, the dielectric constant of water $\varepsilon$ and its dynamic viscosity $\eta$, surface potential $\varphi$ and does not depend on the length and diameter of the channel.

It was found that when the gaps between the channels narrow down in the direction of the friction force, the capillary force, which facilitates the filling of free spaces in narrowing gaps with water, increases. Otherwise, water will be removed from the friction zone.

In fact, the process of wetting the solid surfaces is much more complicated than it follows from equations (3) and (4), since the composition of the phases changes during synthesis, and it is necessary to take into account the initial and final gradients of the contact angles. It has been established that it is the intermediate contact angle gradients that are important for determining the conditions for applying any surface coatings. Thus, the energies of all interphase boundaries change with a change in the overall composition, and both a delay and an increase in the spreading rate can occur. Equation (3) links the values of surface energies of interphase boundaries to the change in measurement time. There is often a significant difference in contact angles, at which either the wetted area increases or water flows out from the initially wetted surface. These differences arise out from a soiled surface or irreversible changes during wetting. Typically, the contact angle should be less for removing water than to propagate it.

\subsection{Influence of Wet Friction Couples on the Operational Parameters of Disc-shoe Brakes of Vehicles}

The stability and reliability of the friction couples of vehicle's disc-shoe brakes are largely determined by the amount of water that irrigates their working surfaces during precipitation. Solid and self-ventilated brake discs are especially not protected from moisture.

Self-ventilated disc-shoe brakes of MAN trucks (model TGA 26.420) with dry and wet friction couples were tested with 20 -fold cyclic braking. The initial vehicle speed was $V_{1}=60 \mathrm{~km} / \mathrm{h}$, the final speed was $V_{2}=30 \mathrm{~km} / \mathrm{h}$. The time of one braking cycle was $1.0 \mathrm{~min}$. For dry friction couples of a vehicle's disc-shoe brake the cyclic braking mode met the requirements of UNECE Regulation No. 13.

The choice of the front brake mechanism is due to the fact that its friction couples are completely wetted when it rains, while the friction couples of the rear brake mechanism - only by $60 \%$. The testing bench with rotating mass $G_{V}=35.8 \mathrm{Nms}^{2}$ simulates the operation of the front brake, and the testing bench with rotating mass $G_{V}=70.6 \mathrm{Nms}^{2}$ simulates the operation of the rear brake. Design of the front disc-shoe brake (Fig. 7) foresees the use of a composite brake disc 1, which consists of left 5 and right 6 half-discs, separated by a heat-insulation layer 7 . Such a configuration of a composite solid disc 1 with different weight characteristics and areas of heat exchange surfaces provides ex- 
perimental data corresponding to real operating conditions. The disc temperature at the beginning of breaking did not exceed $25^{\circ} \mathrm{C}$. The air pressure in the pneumonic cell of the testing bench was within 1.0-1.5 MPa.

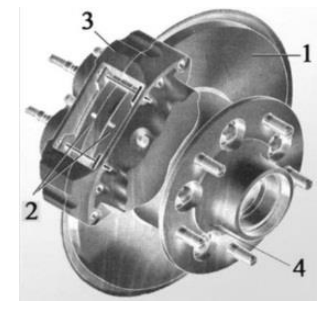

a

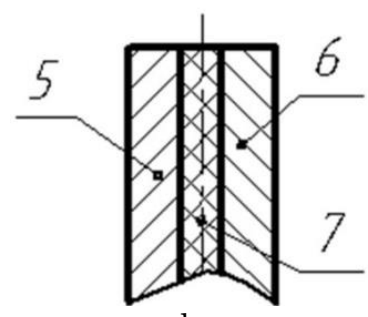

$\mathrm{b}$

Fig. 7 - General view of a disc-shoe brake (a) and its half-discs with a thermal insulation gasket (b): 1 - brake disc; 2 - brake pads; 3 -support; 4 -flange; 5 and 6 - left and right halfdiscs; 7 - heat-insulation layer

At 20 cyclic braking on the testing bench of dry friction couples FK-24 A - steel 35HNL disc-shoe brakes, their surface temperature reached $320-340{ }^{\circ} \mathrm{C}$, i.e. it was below the permissible temperature (390-420 ${ }^{\circ} \mathrm{C}$ ) for the material of friction facing. Then the device for wetting the left half-disc 5 is switched on, continuing the cyclic braking on the testing bench.

The efficacy (contact strength, operating unit loads, energy load, dynamic coefficient of friction, braking torque, durability) of the brake depends on the thickness of the water film. The roughness of the matt and polished (working) surfaces of the disc is very different. This affects the intensity of the water film creation in the microasperity of the indicated surfaces and its (film) thickness. During rotation of the closed brake, the water film layer, which is above the microasperity of the friction belt, is cut off by the front edge of the friction pad.

Depending on the rotation speed of the disc 1, part of water from its surfaces is discharged into the environment under the centrifugal forces. The water liquid phase forms a film with chaotic perforation due to the uneven microasperities' profile of the polished and matt surfaces of the left half-disc 5. At a volumetric temperature $t_{1}$ above $100{ }^{\circ} \mathrm{C}$, the water liquid phase turns into a vapor phase, and water sprinkling the polished and matt surfaces of the left half-disc 5 falls on the steam pad. In this case, a two-phase medium (water + steam) washes the surfaces of the left half-disc 5. Therefore, with the two-phase medium formation, the meaning of the classical concepts of "contact angle" and "heat of wetting" is lost.

Let us consider the main thermodynamic parameters (temperature, quantity of heat, heat transfer coefficient) of dry and wet friction couples of disc-shoe brakes (Table 1).

Table 1 - Thermodynamic parameters of dry and wet friction couple FK-24A - steel 35HNL of the left half of the brake

\begin{tabular}{|c|c|c|c|}
\hline \multirow{5}{*}{$\begin{array}{c}\text { Friction } \\
\text { couple } \\
\text { FK-24A - } \\
\text { steel 35HNL }\end{array}$} & \multirow{5}{*}{$\begin{array}{c}\text { Temperature } \\
\text { values } t,{ }^{\circ} \mathrm{C}\end{array}$} & \multicolumn{2}{|c|}{ Calculated dependences to determine } \\
\hline & & \multicolumn{2}{|c|}{ Quantity of heat, Qi, J } \\
\hline & & Generated & $\begin{array}{c}\text { Diverted by washing } \\
\text { environments }\end{array}$ \\
\hline & & \multicolumn{2}{|c|}{ By the heat transfer coefficients, $a \mathrm{~W} /\left(\mathrm{m}^{2}{ }^{\circ} \mathrm{C}\right)$} \\
\hline & & \multicolumn{2}{|c|}{ By dry air } \\
\hline \multirow{2}{*}{ Dry } & \multirow{2}{*}{$320-340$} & $Q_{1}=m c_{1}\left(t_{k}-t_{0}\right)(5)$ & $Q_{2}=G_{v i} \cdot c_{2} \cdot \Delta t_{1}$ \\
\hline & & $\alpha_{1}=Q_{1} /\left(A \cdot \tau_{1} \cdot \Delta t_{2}\right)$ & $\alpha_{2}=Q_{2} /\left(A \cdot \tau_{2} \cdot \Delta t_{3}\right)$ \\
\hline \multirow{3}{*}{ Wet } & \multirow{3}{*}{$200-215$} & By humid air & $\begin{array}{c}\text { By two-phase environment } \\
\text { (water + steam) }\end{array}$ \\
\hline & & $Q_{3}=m \cdot c_{3} \cdot \Delta t_{4}(9)$ & $Q_{4}=G_{v 2} \cdot c_{\mathrm{mp}} \cdot \Delta t_{5}$ \\
\hline & & $\alpha_{3}=Q_{3} /\left(A \cdot \tau_{3} \cdot \Delta t_{4}\right)(10)$ & $\alpha_{1}=Q_{4} /\left(A \cdot \tau_{4} \cdot \Delta t_{5}\right)$ \\
\hline
\end{tabular}

In dependences (5)-(12) of Table 1, the following symbols are used: $m$ is the mass of the left half-disc; $c_{1}$, $c_{3}$ are the specific heat capacities of the surface layer of the half-disc; $c_{2}, c_{p r}$ are the specific heat capacities of washing environments; $t_{k}, t_{0}$ are the final heating temperature of the half-disc and the ambient air; $\Delta t$ is the change in surface temperature in the considered thermal processes; $A$ is the area of the heat exchange surface of the left half-disc; $\tau$ is the time of the process; $G_{v i}$ is the flow rate of the environments that are washing the left half-disc surfaces.

Table 1 did not include the dependences concerning the heat exchange processes of a brake pad with a lining, since their effect on the overall thermal balance of the brake friction couples is insignificant.

The calculations' results performed according to dependences 5-12 showed that dry friction couples are $30 \%$ more effective than wet ones. In addition, in wet friction couples:

- to ensure traffic safety, the downforce and consequently the specific loads must be increased by $15-20 \%$; 
- the dynamic coefficient of friction is 15-25\% lower that leads to a decrease in the braking torque;

- wearing process of the friction surfaces increases by 10-15\% due to intense hydrogen wear.

Fig. 8 shows the regularities of the surface temperature changes $t_{s}$, which is a function of the cooling water flow rate at the averaged values of the disc rotation speed and the developed braking torque of a selfventilated disc-shoe brake of a MAN model TGA26.420 with spikes. The analysis of the graphical dependence showed that the cooling effect of water increases with an increase in its consumption.

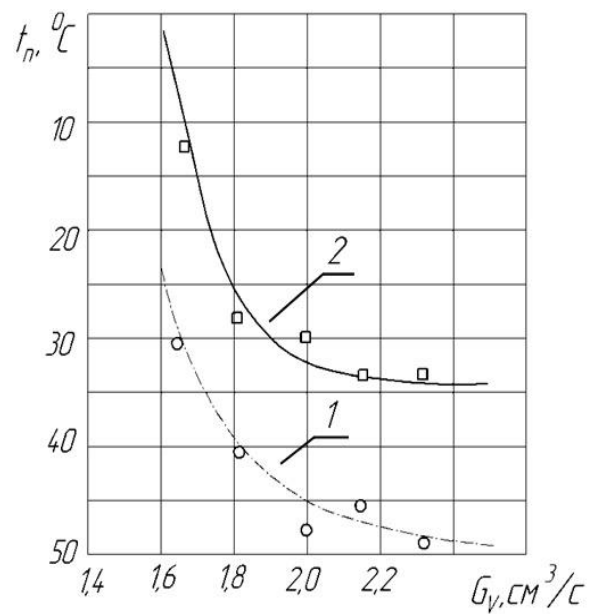

Fig. 8 - Changes in the surface temperature $t_{s}$ of the left halfdisc friction belt of the self-ventilated disc with the front brake spikes of MAN (model TGA 26.420) depending on the cooling water consumption $G_{V}$ at $\omega=\mathrm{s}^{-1}: 1-M_{T}=145.0 \mathrm{Nm} ; 2-$ $M_{T}=195.0 \mathrm{Nm}$

Designers and operators include in the design dependences the minimum value of the dynamic coefficient, making a correction for the presence of moisture. This does not take into account the different degree of contamination of polished and matt surfaces of vehicle brake discs.

Let us analyze the graphical dependences of the form $M=\mu(f), x=\mu(f), \tau=\mu(f)$ (Fig. 9). According to the first graphical dependence (Fig. 9a), with an increase in the dynamic coefficient of friction, the braking torque increases, but the braking distance and braking time of the vehicle decrease (Fig. 9b, c). It was found that with an increase in the dynamic coefficient, the friction between brake friction couples of a tribological layer, which contributes to the stabilization of the braking parameters, is formed $(M, X$ and $\tau$ marked by rectangles in Fig. 9).

\section{DISCUSSION OF THE RESULTS}

The results of theoretical and experimental studies of wet friction couples of vehicles' disc-shoe brakes operated with different degrees of water irrigation allow us to state the following:

- the area of wetted surface depends on the nature and structure of the wetting phase, as well as on the purity and micro-profile of the disc surface. When irrigated with water, the area of the wetted surface depends on the number of atoms with high electronega- tivity per unit area. When determining the actual area of frictional interaction, it was assumed that water, joining the gas products, forms a monomolecular layer that facilitates filling the space between the surface microstructures with moisture;
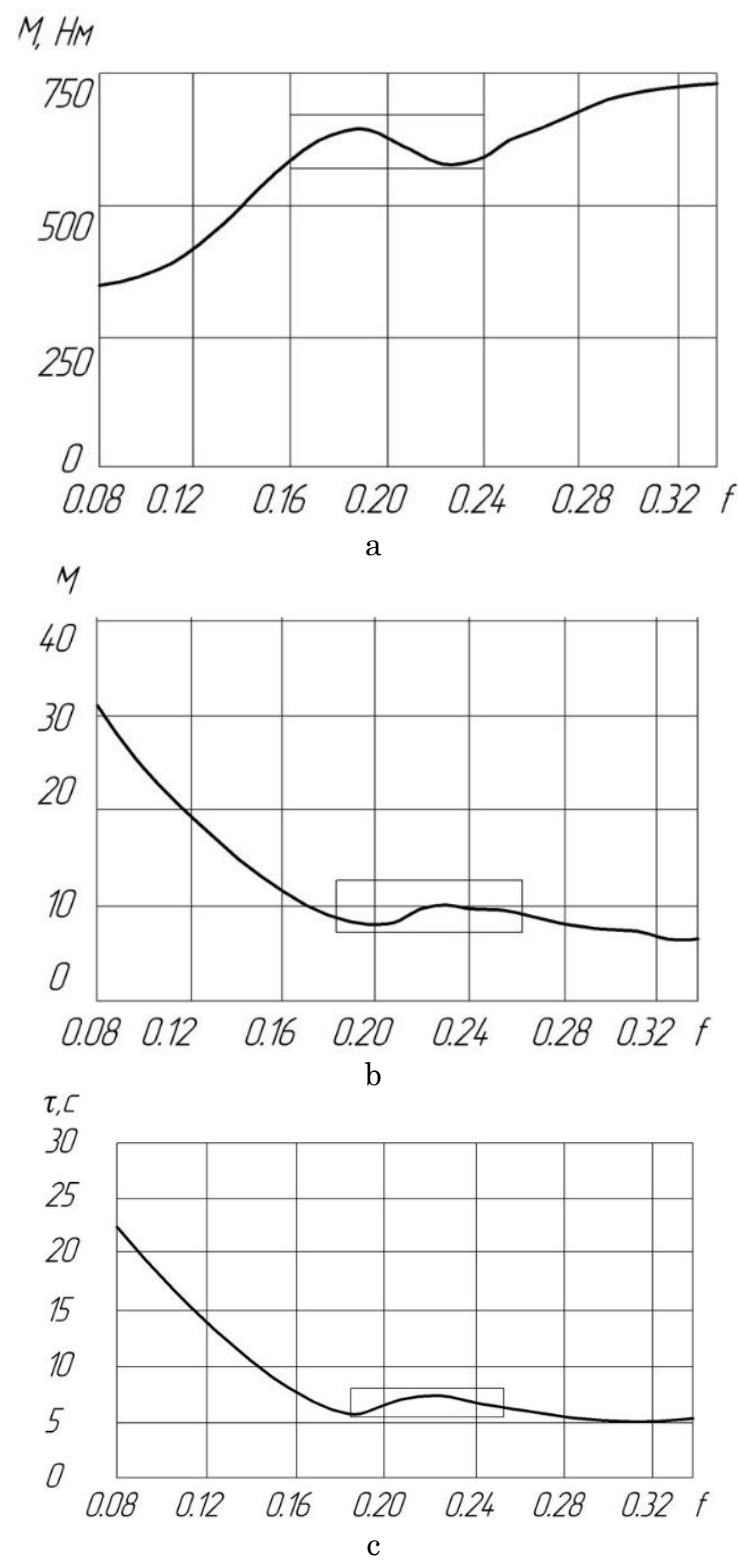

Fig. 9 - Regularities of the change in the braking torque (a), braking distance (b) and braking time (c) depending on the dynamic coefficient of friction of the front disc-shoe brake wet friction units of a truck MAN (model TGA 26.420)

- the driving force in the processes occurring in the microchannels between the microasperities of the discs friction belts is the potential difference arising from the action of transverse and longitudinal double electric layers when the working surface of the lining moves along the new trace of the disc friction belt;

- the asymmetric temperature distribution over the surface of the water film of the disc friction belt is due to the fact that in the vicinity of the heated spot, a divergent flow arises in the film because of the change in the surface tension (thermocapillar effect). This leads to rupture of the film where the temperature is maxi- 
mum. Film rupture can occur along a certain circumference, where the temperature gradient is more significant. As a result, a disc of water is formed in the center, which due to surface tension transforms into a toroidal formation and then, after oscillations, into a drop. Later, the drop gradually evaporates;

- if the gaps between microasperities' channels narrow down in the direction of the friction force, the capillary force grows in the same direction, contributing to the effect of water absorption into the pores of the narrowing gaps (confuser effect). Otherwise, water will be removed from the friction zone;

- increasing the humidity of the air which is flowing around the friction couple, its friction moment and surface temperature decrease by an average of 25-40\%;

- with an increase in the vehicle's speed, the amount of water falling on the outer surface of the brake disc is much greater than on the inner one. The rear axle brake discs receive up to $60 \%$ less water than the front axle;

- with an increase in air relative humidity due to a decrease in braking torque, the braking distance increases, and in order to avoid this it is necessary to create large specific loads on the friction surface;

- a reduction in the amount of water falling on the surface of the discs can be achieved using protective covers, making holes and grooves of various profiles, configurations and locations; applying superhydrophobic coating on the surface of discs using nanotechnology, etc.

\section{CONCLUSIONS}

1. It has been proved that in most cases the movement of water through the channels between microasperities of the friction couple "metal-polymer" leads to the appearance of electric like and unlike charges on their surfaces, as well as on the boundary layer of water, which contributes to the formation of double electric layers. The thickness of the latter in water is tens to hundreds of nanometers and can be comparable to the radius of the microchannel. This circumstance affects both the properties of water itself and the nature of its movement.

\section{REFERENCES}

1. A.Kh. Dzhanakhmedov, A.I. Volchenko, M.Ya. Javadov, V.S. Skrypnyk, I.O. Bekish, V.S. Vitvitsky, Bulletin of the Azerbaijan Engineering Academy 11 No 2, 15 (2019).

2. T. Cherepova, G. Dmitrieva, O. Tisov, O. Dukhota, M. Kindrachuk, Acta Mechanica et Automatica 13 No 1, 57 (2018).

3. M.V. Kindrachuk, Yu.Ya. Dushek, M.V. Luchka, Poroshkovaya metallurgia 9-10, 56 (1994).

4. M. Mitschke, H. Braun, "Deutsch Kraftfahrtforsch Und Strassenverkehrstechn" 240, 31 (1970).

5. M. Jahn, "Kraftfalirzeugtechnik" 3, 74-76, 77 (1976).

6. B.I. Kostetskiy, Friction, lubrication and wear in machines (Kiev: Technika: 1980).

7. I.V. Kragelsky, Friction and wear (M.: Mashinostroenie: 1986).

8. W. Tarasiuk, K. Golak, Yu. Tsybrii, O. Nosko, Wear 456457, 203361 (2020).

9. B.V. Deryugin, Friction and wear in machines (Academy of Sciences of the USSR: 1947).
2. The results of studying the processes occurring with moisture in the micro-grooves of the friction surfaces "pad-disc" showed that transverse and longitudinal double electric layers are formed on the surfaces, which are under study. The transverse type is characterized by the frictional interaction "the working surface of the pad - the upper half-layer of water" and "the lower half-layer of water - the surface of the friction belt of the disc". The longitudinal type is in the line with: "the surface of the microasperities' tops of the disc friction belt" (negatively charged) - "a layer of water between the microasperities" (negatively charged); "the surface of the microasperities' tops of the friction pad" (positively charged) - "a layer of water between the microasperities" (negatively charged).

The survivability of transverse electric double layers in time is much less than that of longitudinal ones.

3 . It is shown that as a result of electric charges existence in water, the imposition of an external electric field causes electro-osmosis, as a result of which water moves through the channels. The speed of water movement supported by the electro-osmatic pump depends on the strength of the applied field, the dielectric constant of water and its dynamic viscosity, surface potential and does not depend on the geometric dimensions of the channel.

4. It was found that due to a change in the surface tension of a heated water film, a divergent current arises in it (thermocapillary effect or Marangoni effect). The same effect is caused by similar charges of an electric double layer.

5 . It is noted that penetration of water on the disc friction belt is extremely undesirable, since it facilitates the decrease in the friction dynamic coefficient of the friction unit and, as a consequence, engineerable braking torque. On the other hand, the tribological effect goes down together with the work due to friction, which is a positive sign.

6. It has been established that in the frictional interaction process of the brake friction couples, two interdependent processes take place: the first is the activation of the metal friction surface and an increase in its free energy; the second - the water film reduces to a minimum the free surface energy due to shielding.

10. A.D. Zimon, Liquid adhesion and wetting (M.: Chemistry: 1974)

11. G.I. Fuks, Friction and Wear 4 No 3, 398 (1983).

12. M.V. Kindrachuk, V.E. Marchuk, A.I. Dukhota, Technological support of wear resistance of parts of tribomechanical systems with discrete surfaces (Kyiv: NAU: 2020).

13. V. Marchuk, M. Kindrachuk, O. Tisov, A. Kornienko, O. Radko, V. Kharchenko, Funct. Mater. 26(4), 773 (2019).

14. A.Kh. Dzhanakhmedov, A.I. Volchenko, K.T. Nabizade, Tribology: friction, wear, lubrication (Baku: Apostrof-A, 2019).

15. M.V. Kindrachuk, A.I. Vol'chenko, D.A. Vol'chenko, D.Y. Zhuravlev, V.M. Chufus, Mater. Sci., 54, 71 (2018)

16. N.A. Volchenko, P.S. Krasin, D.A. Volchenko, A.V. Voznyi, IOP Conf. Ser.: Mater. Sci. Eng. 327, 032059 (2018).

17. N. Volchenko, A. Volchenko, D. Volchenko, P. Poliakov, V. Malyk, D. Zhuravlev, V. Vytvytskyi, P. Krasin, EasternEuropean Journal of Enterprise Technologies 1/5 (97), 473 (2019). 
18. M.V Kindrachuk, O.I. Volchenko, D.O. Volchenko, N.O. Volchenko, P.O. Polyakov, A.O. Kornienko, A.O. Yurchuk, J. Nano- Electron. Phys. 11, 3, 03014 (2019).

19. N.A. Volchenko, D.A. Volchenko, P.A. Polyakov, E.S. Fedotov, A.S. Evchenko, IOP Conf. Ser.: Mater. Sci. Eng. 560 (1), 012194
(2019).

20. M. Kindrachuk, A. Volchenko, D. Volchenko, O. Tisov, A. Kornienko, Funct. Mater. 26 (3), 629 (2019).

21. M.V. Kindrachuk, O.I. Volchenko, D.O. Volchenko, V.S. Skrypnyk, A.V. Voznyi, Mater. Sci. 54, 843 (2019).

\section{Електротермомеханічне тертя мокрих деталей автомобільних дисково-колодкових гальм}

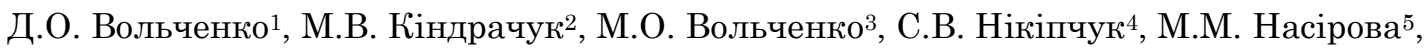
Н.В. Клочко ${ }^{1}$ А.О. Юрчук ${ }^{2}$

${ }_{1}^{1}$ Івано-Франківський національний технічний університет нафтии і газу, вул. Карпатська, 15, 76000 Івано-Франківськ, Украӥна

${ }^{2}$ Національний авіаційний університет, пр. Люболира Гузара, 1, 02000 Київ, Украӥна

${ }^{3}$ Кубанський державний технічний університет, вул. Московська, 2, 350042 Краснодар, Росія

${ }^{4}$ Національний університет "Львівська політехніка", вул. Степана Бандери, 12, 79000 Львів, Україна

${ }^{5}$ Азербайджанська авіаційна академія, пр. Мардакан, 30, Баку, Азербайджан

У статті звернено увагу на фактори, що впливають на граничний кут змочування як полірованих, так і матових бічних поверхонь твердих та самовентильованих дисків гальмівних пристроїв транспортних засобів, коли вони рухаються по мокрому дорожньому полотну. Розглядаються такі фактори: матеріал елементів пари тертя та їх структура, енергетичний рівень поверхневого шару, топографія поверхонь тертя та геометричні параметри їх мікровиступів і мікровпадин, наявність в них пор і пазів, капілярний, відцентровий і інерційні сили та моменти, динамічна рівновага між рівнем енергії подряпин внаслідок тертя та водяної плівкою на поверхні. При дослідженні мікрогеометрії поверхні тертя диска враховувались її площа, відношення висоти мікронерівностей до їх кроку, інтенсивність змін їх висоти та ступінь забруднення. Було встановлено, що мікрогеометрія поверхні впливає на теплоту десорбції водної плівки. Дослідження вищезазначених фракторів показало, що рушійною силою процесів та ефектів у мокрих гальмівних системах е градієнти потенціалу, що виникають в результаті діі поперечних та поздовжніх електричних подвійних шарів. Досліджено трибоелектричні явища, на які впливае присутність води. Представлені результати випробувань самовентильованих дискових гальм дисково-колодкового типу автомобіля MAN моделі TGA 26.420 із сухими та мокрими гальмами, випробуваних із 20-кратним гальмуванням (падіння швидкості 30 км/год за 1 хв.). Зареестрована температура на поверхні тертя склала $320-340^{\circ} \mathrm{C}$. В результаті дорожніх випробувань на вантажівці 3 мокрими гальмівними пристроями були встановлені закономірності часу гальмування, гальмівного моменту та зміни гальмівного шляху від динамічного коефіціента тертя. Проведено аналіз отриманих даних. Наведено результати досліджень негативного ефекту проникнення води всередину дисковоколодкових гальм.

Ключові слова: Дисково-колодкові гальма, Пара тертя, Мікровиступ, Вода, Пара, Поздовжній і поперечний подвійний електричний шар. 